TOMASZ GARBOL

\title{
KAROL WOJTYŁA A NOWOCZESNOŚĆ
}

\section{OSOBNOŚĆ}

Krzysztof Dybciak w artykule prezentującym czytelnikowi zagranicznemu twórczość Karola Wojtyły dwa lata po jego wyborze na papieża usytuował ją w kontekście refleksji dotyczącej specyfiki polskiego życia intelektualnego, polegającej na tym, że: „Myśl polska zawsze chętnie szukała literackich form przekazu” („Poetycka fenomenologia” 150)1. Jako myślicieli-pisarzy wskazał „największych polskich mistyków": Konstancję Benisławską, Adama Mickiewicza, Juliusza Słowackiego, Cypriana Norwida; myślicieli politycznych: Maurycego Mochnackiego, Zygmunta Krasińskiego, Stanisława Brzozowskiego; filozofów: Floriana Znanieckiego, Witkacego, Tadeusza Kotarbińskiego, Leszka Kołakowskiego i ks. Józefa Tischnera („Poetycka fenomenologia” 150). Najbliższego myślowo Wojtyle poetę - Norwida - literaturoznawca określił jako „wybitnego nowatora teologii” („Poetycka fenomenologia" 150). Wskazanie na rys nowatorski u Norwida współbrzmi z wyborem innych twórców - wybitnych i oryginalnych myślicieli polskiego modernizmu, na przykład Witkacego i Stanisława Brzozowskiego. Inni autorzy przywołani przez Dybciaka też okazują się oryginalnymi myślicielami z kręgu modernizmu. Leszek Kołakowski - jako pisarz i filozof tej jego odmiany, która jest „wieloaspektową teorią kultury oraz jej wytworów, badaniem kulturowych aspektów i konsekwencji nowoczesności - zwłaszcza dla zrozumienia człowieka" (Bolecki 88). Z kolei Florian

Dr hab. Tomasz Garbol - adiunkt Ośrodka Badań nad Literaturą Religijną w Instytucie Literaturoznawstwa KUL; adres do korespondencji: Katolicki Uniwersytet Lubelski Jana Pawła II, Al. Racławickie 14, 20-950 Lublin; e-mail: tomeus@kul.pl. ORCID: http://orcid.org/0000-00015411-0780.

${ }^{1}$ Pierwodruk w języku angielskim „The Poetic Phenomenology of a Religious Man. About the Literary Creativity of Karol Wojtyła” 223. 
Znaniecki - według tej samej interpretacji zróżnicowania polskiego modernizmu autorstwa Włodzimierza Boleckiego - to modernistyczny katastrofista (Bolecki 256).

Dybciak nie tylko pośrednio umieszcza twórczość Wojtyły w kontekście modernistycznym, ale również wskazuje na takie jej cechy, które z perspektywy dobrze już dzisiaj ugruntowanej refleksji nad modernizmem okazują się związane z tą formacją kulturową i artystyczną. Artykuł Wojtyły O humanizmie św. Jana od Krzyża badacz traktuje jako ,autokomentarz polskiego poety-teologa” („O humanizmie św. Jana od Krzyża” 8). W nim zaś Wojtyła zauważał: „Poezja niewątpliwie ułatwiła Autorowi wiele w tej dziedzinie, która ani w ramach potocznego prozaicznego języka, ani w więzach ściśle naukowej terminologii, nie da się współrzędnie wyrazić" („O humanizmie św. Jana od Krzyża” 8). Przekonanie, że poezja potrafi wyrazić więcej niż tradycyjny język teologicznego opisu doświadczeń religijnych współbrzmi z konkluzją rozważań Charlesa Taylora dotyczących ,epifanii modernizmu”: „Nie sposób po prostu wydobyć z dzieła samorodka prawdy transcendentnej: jest on nieodłącznie związany z dziełem ..." (Źródła podmiotowości 908). Taylor traktuje to trwałe zespolenie ${ }^{2}$ duchowego znaczenia z dziełem sztuki jako wyraz „nieprzemijającej ważności romantycznej doktryny symbolu" (Źródła podmiotowości 908). W późniejszej książce The Language Animal konstatuje on bezpośredni związek romantycznego pojmowania sztuki jako symbolu (234) z przekonaniem o zarówno jej „nieprzekładalności” (untranslatability) na asercje, jak i niewyrażalności pewnych obszarów doświadczenia ludzkiego poza językiem sztuki (247). Tę drugą tezę wzmacnia w rozważaniach Taylora analiza języka muzyki dokonana przez Rogera Scrutona - jego znamienna uwaga: „Sztuka urzeczywistnia (realizes) to, co inaczej pozostaje nieokreślone, nieukształtowane i niekomunikatywne" (The Language Animal 247) ${ }^{3}$.

Zdecydowanie odmienne stanowisko w kwestii relacji pomiędzy twórczością Jana Pawła II i nowoczesnością zajmuje Andrzej Skrendo, według którego „Tryptyk rzymski [...] nie mieści się w dziejach poezji nowoczesnej” (Skrendo 245). Mają o tym świadczyć: podzielane przez Autora poematu „przeświadczenie o niepełnej autonomii literatury i wszelkiej sztuki w ogóle" (Skrendo 243); przyjęcie soteriologicznej perspektywy fałszywie unieważniającej istotne dylematy artysty nowoczesnego (w tym konflikt między instytucją Kościoła i artystą); naiwna wiara w mimetyczność literatury, lekceważąca dylematy artysty nowoczesnego w tym zakresie (Skrendo 244-245).

${ }^{2} \mathrm{~W}$ oryginale pojawia się sformułowanie ,inseparably imbedded in the work” (Sources of the self: the making of the modern identity 492).

${ }^{3}$ Taylor cytuje tutaj fragment książki Rogera Scrutona (Scruton 352). 
Skrendo odnajduje dodatkowe potwierdzenie swojego rozpoznania w interpretacjach i komentarzach do poematu zamieszczonych w zbiorowym tomie Wokót „Tryptyku rzymskiego”. Autorem jednej z nich jest Krzysztof Dybciak. Porównanie zasadniczej linii interpretacyjnej przyjętej w jego studium o Tryptyku z wcześniejszym wprowadzeniem tego samego badacza do twórczości Karola Wojtyły prowadzi do konstatacji wyjaśniającej w pewnym stopniu radykalizm stanowiska Skrendy. Dybciak interpretuje bowiem Tryptyk rzymski i całą poezję jego Autora, akcentując wierność tradycji i przeciwstawiając ją obecnym w poezji polskiej różnym odmianom kontestacji ortodoksji:

Wyjątkowość poezji Wojtyły-Jana Pawła II polega na jej ortodoksyjnej religijności, poprawności teologicznej, respektowaniu tradycji. Wcześniej religijno-metafizyczna poezja w języku polskim sytuowała się nierzadko na granicy herezji [...]. Karol Wojtyła-Jan Paweł II tworzy poezję głęboką myślowo, żarliwie uduchowioną, zawierającą pierwiastki mistyczne, ale bez przekraczania prawd zawartych w chrześcijańskim Objawieniu i bez opuszczania wspólnoty Kościoła. (Trudne spotkanie 253)

Badacz, który wcześniej podkreślał wrażliwość Wojtyły na wyjątkowość języka poezji, na jego większe od języka teologicznego możliwości wyrażania doświadczeń religijnych, w papieskim poemacie dostrzegł przede wszystkim wierność tradycji manifestującej się w formułach ortodoksyjnej teologii. Tryptyk rzymski objawił się dwu różnym czytelnikom - zarówno przekonanemu o jego wysokiej wartości artystycznej, jak i wątpiącemu w nią - przede wszystkim jako głos w obronie tradycji wiary katolickiej.

Takie stanowisko współbrzmi z podzielanym przez wielu badaczy przekonaniem, że poezja Wojtyły jest w literaturze polskiej zjawiskiem osobnym, niezależnym od wpływów literackiej nowoczesności. Wiesław Paweł Szymański zauważył nawet, że twórczość ta: „Nie uległa ... presji nowoczesnej estetyki” (Szymański 15-16). Jedynie w juwenilnych tekstach Wojtyły dostrzega się czasami związki z artystycznym klimatem epoki. Na przykład Anna Kozłowska odnajduje w nich: „Ślady fascynacji twórczością Słowackiego i jego poetyckich spadkobierców modernistów ...” („Wobec tradycji literackiej” 389). Literaturoznawcza recepcja twórczości Karola Wojtyły i Jana Pawła II różni się więc od modelu jej rozumienia na płaszczyźnie filozoficznej i teologicznej. Tutaj bowiem dosyć często przyjmuje się, że Wojtyła-filozof, a potem także Jan Paweł II papież projektował swoją twórczość jako odpowiedź na wyzwania nowoczesności, również w jej tak zwanej „późnej” odmianie. Amerykański biograf Jana Pawła II, filozof, George Weigel rekonstruuje postawę badawczą Wojtyły-filozofa $z$ lat powstawania jego rozprawy habilitacyjnej oraz książki Osoba i czyn, podkreślając w dziełach swojego bohatera wyraźną potrzebę nawiązania dialogu z myślą współczesną: „Niektóre postaci neoscholastyki 
mogły stanowić przeszkodę dla prawdziwego spotkania katolicyzmu z nowoczesną filozofią. Wojtyła po prostu obszedł tę barierę, wchłonąwszy z neoscholastyki to, co było w niej trwałe - przekonanie, że filozofia może dotrzeć do prawdy rzeczy-takich-jakimi-są" (Weigel 168-169). Z kolei dla następcy kardynała Wojtyły na katedrze metropolii krakowskiej, ks. abp. Marka Jędraszewskiego, w jego filozoficzno-teologicznej lekturze Tryptyku rzymskiego, podstawowym przeświadczeniem jest przekonanie, że główny kontekst myślowy tego poematu to późna nowoczesność (Jędraszewski, „»Przemijanie ma sens«” 240). Bliższe dookreślenie tego kontekstu prowadzi do stwierdzenia, że „ontologia zawarta w Tryptyku jawi się jako wyraźna polemika z Sartre'em” (,»Przemijanie ma sens «” 245). Dobra znajomość myśli filozofów nowoczesnych - a więc samego rdzenia modernizmu jako formacji kulturowej - wydaje się oczywista z punktu widzenia stanowisk wyrażonych przez tak ważnych interpretatorów myśli Jana Pawła II, jak abp Jędraszewski czy Weigel. Ujęcie pierwszego z tych autorów - identyfikujące relację pomiędzy dziełem Jana Pawła II i nowoczesnością jako krytyczny sprzeciw w stosunku do kultury późnej nowoczesności (,»Przemijanie ma sens«” 240) - jest modelowe dla wielu odczytań działalności i twórczości Papieża z Polski ${ }^{4}$.

\section{NOWOCZESNOŚĆ?}

Po niemal dwóch dekadach od opublikowania poematu jawi się on jako w pełni samodzielny utwór poetycki wieńczący twórczość Karola Wojtyły. Drugoplanowe okazują się teksty - kardynałów Franciszka Macharskiego i Josepha Ratzingera towarzyszące jego pierwszemu wydaniu, potraktowane przez krytyka jako dodatkowy dowód antynowoczesności utworu: „Nikt tak dziś nie wydaje poezji, nikt tak nie dziękuje za wiersze" (Skrendo 244)5.

Z tej dłuższej perspektywy - obejmującej pontyfikaty dwóch następnych po Janie Pawle II papieży, z których żaden przecież nie opublikował poematu - istotna wydaje się również konstatacja, że chociaż w dziejach papiestwa bywali biskupi Rzymu będący poetami (np. Hilary, Mikołaj III umieszczony przez Dantego w piekle czy Pius II), to w ostatnich dwustu latach konfrontowania się Kościoła i jego kolejnych

\footnotetext{
${ }^{4}$ Krzysztof Dybciak we wstępie do antologii tekstów o Janie Pawle II konstatuje zasadniczą sprzeczność pomiędzy duchem ,dzieł świętego Papieża” a ponowoczesnym relatywizmem (Pisarstwo Karola Wojtyly - Jana Pawła II w oczach krytyków i uczonych 27).

${ }^{5}$ Jest oczywiste, że do korpusu dzieł Karola Wojtyły - Jana Pawła II należy tylko poemat. Zrozumiałe jest więc, że obydwa wspomniane teksty kardynałów nie znalazły się w edycji całości jego twórczości literackiej w opracowaniu M. Skwarnickiego, opublikowanej rok przed śmiercią Autora (Poezje, dramaty, szkice).
} 
głów z różnymi wyzwaniami nowoczesności Karol Wojtyła okazuje się pod względem aktywności literackiej wyjątkiem. Ta wyjątkowość dobrze zresztą współgra ze zmianami wprowadzonymi przez Jana Pawła II w formach sprawowania urzędu papieskiego. Gdyby zatem wziąć pod uwagę zewnętrzny wobec poematu kontekst pontyfikatu Papieża z Polski, to właśnie w takim aspekcie - okoliczności czyniących ów pontyfikat nowoczesnym pod wieloma względami.

Autor poematu jest też jedynym w dziejach papieżem kierującym do artystów tak zwany list apostolski. Sam ten dokument zaś - akcentujący niewyrażalność pewnych doświadczeń poza językiem sztuki - współbrzmi z nowoczesnym pojmowaniem roli artysty:

\begin{abstract}
Wszyscy artyści zdają sobie sprawę, jak głęboka przepaść istnieje między dziełem ich rąk, nawet najbardziej udanym, a olśniewającą doskonałością piękna, dostrzeżonego w chwili twórczego uniesienia: wszystko, co zdołają wyrazić malując, rzeźbiąc i tworząc, jest jedynie przebłyskiem owej światłości, która na kilka chwil zajaśniała oczom ich duszy. ... Czyż można się zdumiewać, że duch zostaje niejako porażony tą wizją do tego stopnia, iż potrafi to wyrazić tylko nieudolnym bełkotem? Jeśli nawet wewnętrzna prawda rzeczy pozostaje zawsze „poza granicą” ludzkiej zdolności rozumienia, o ileż bardziej dotyczy to Boga, ukrytego w swej niezgłębionej tajemnicy! (Wojtyła, Poezje, dramaty, szkice 565-566)
\end{abstract}

Papież zwraca więc uwagę na prawo artystów do uznania „prawdy rzeczy” za niewyrażalną, a samych prób w tym zakresie za usiłowania „bełkotliwe”. Następny fragment Listu nie podważa więc autonomii literatury, ale potwierdza przywiązanie do nowoczesnego przekonania, że artysta potrafi niekiedy wyrazić więcej niż teolog: „Sztuka bowiem, jeżeli jest autentyczna, choć niekoniecznie wyraża się w formach typowo religijnych, zachowuje więź wewnętrznego pokrewieństwa ze światem wiary, tak że nawet w sytuacji głębokiego rozłamu między kulturą a Kościołem właśnie sztuka pozostaje swego rodzaju pomostem prowadzącym do doświadczenia religijnego" (Poezje, dramaty, szkice 572). Nie jest to zaprzeczenie autonomii sztuki, ale uznanie jej uprzywilejowanej roli w wyrażaniu ludzkiego doświadczenia. Istotne okazuje się tutaj nie tyle to, że sztuka ma służyć zbawieniu, ile to, że zbawienie dokonuje się dzięki pomocy sztuki. Dopełnieniem tak zarysowanej perspektywy okazuje się przywołanie formuły Dostojewskiego: „Piękno zbawi świat”. Pełni ona w Liście rolę komentarza do Promethidiona Cypriana Norwida (Poezje, dramaty, szkice 562), ale zarazem świadczy o współuczestnictwie w namyśle nad nowoczesnymi dylematami sztuki. Ten sposób myślenia staje się w pełni zrozumiały jako współtworzący nurt dobrze już ugruntowanej refleksji nad uniezależnieniem piękna od dobra, przybierającym czasami postać przeciwstawienia piękna i dobra.

W polskiej literaturze współczesnej dziełem syntetycznie ujmującym takie dychotomiczne ujęcie jest wiersz Czesława Miłosza Poznanie dobra i zła: „I dobro jest słabe, ale piękno silne. / ... // Kiedy ludzie przestaną wierzyć, że jest zło i jest 
dobro, / Tylko piękno przywoła ich do siebie i ocali. / Żeby umieli powiedzieć: to prawdziwe, a to nieprawdziwe" (Miłosz 803). Do tego właśnie wiersza Miłosza odnosi się Gregory Wolfe (Wolfe XVI), traktując polskiego poetę oraz Aleksandra Sołżenicyna jako dwóch ważnych świadków zmagań z totalitaryzmem. Wolfe zwraca uwagę na problematyczność wyboru dobra - opcji często niedostępnej dla osób kwestionujących ideowe podstawy koncepcji dobra, a czasami kierujących się uprzedzeniami wobec nich. Inaczej jest $\mathrm{z}$ wyborem piękna, dokonującym się dzięki pociągnięciu ku niemu ludzkich zmysłów i całej postawy egzystencjalnej - Wolfe metaforycznie mówi o tej roli piękna, że „usuwa ostre krawędzie prawdy i dobra" - „takes the hard edges off truth and gooddness" (Wolfe 46). W historii idei filozoficzną podstawą oddzielenia dobra od piękna jest nadanie przez Kanta wyższej normatywnej doniosłości temu, co estetyczne, i stworzenie możliwości „całościowego podważenia prymatu moralności” (Taylor, Źródła podmiotowości 781), a następnie proklamowania kontrmoralności sztuki, to znaczy takiej jej hierarchii, że za nieśmiertelne uznaje się tylko te jej dokonania, które są wolne od zachęt do czynienia dobra lub zła (781).

O tym, jak głęboko Karol Wojtyła był przejęty nowoczesnością, świadczy jego słynna praca Osoba i czyn. Została ona ogłoszona jako wyraz przekonania, że: „Człowiek nie może zagubić właściwego sobie miejsca wśród tego świata, który sam ukształtował - a takim jest świat kultury i cywilizacji: właśnie ów »świat współczesny «" (Osoba i czyn 25). To stanowisko było ważnym punktem odniesienia w pracach nad konstytucją Gaudium et spes, w których krakowski Kardynał uczestniczył. Osobiste wyznanie Autora przypisujące dziełu intencję tożsamą z zamierzeniami autorów konstytucji soborowej potwierdza, że Karolowi Wojtyle zależało na dialogu ze współczesnością. Jeden z badaczy jego twórczości intensywność owej gorliwości ujawnioną w Osobie i czynie określa obrazowo jako dążenie „do przelicytowania nowoczesnego subiektywizmu i aktywizmu, fetyszyzmu zaangażowania”, zamierzenie, aby udowodnić ,światu, że inspirowany chrześcijaństwem, choć nie otwarcie, chrześcijański aktywizm jest właściwą, »integralną« odpowiedzią na rzeczywiste potrzeby »człowieka i świata współczesnego«" (Grad 153). Chodziło o to, by przekonać zwolenników nowoczesnej filozofii podmiotu, że chrześcijańska antropologia jest możliwa do wyrażenia w ich języku filozoficznym.

W Tryptyku rzymskim nie ma co prawda radykalnego przeciwstawienia sztuki i moralności, ale słychać w nim echo tej poromantycznej refleksji. Widzialny świat pozwala się człowiekowi poznawać w granicach dobra i zła: „Przedwieczne Słowo jest jak gdyby progiem, / za którym żyjemy, poruszamy się i jesteśmy” (Wojtyła, Poezje, dramaty, szkice 514). Stworzenie jest dziełem boskiego widzenia - niejako potwierdzającego, że byt i dobro są zamienne. Człowiek ma jednak wgląd w tę tajemnicę Boskiej percepcji za pośrednictwem widzenia artysty - nie tylko 
uprzywilejowanego, bo naśladującego Boskie widzenie, ale i mogącego przekraczać próg dobra i zła. W Tryptyku rzymskim pada pytanie: „Jak uczynić widzialnym, jak przeniknąć poza granice dobra i zła?" (Poezje, dramaty, szkice 513). Bezpośrednią motywacją tego pytania jest sięgnięcie do tajemnicy kresu i początku. Wyjście poza granice dobra i zła ma tutaj swoje teologiczne uzasadnienie, którym jest intuicja obcowania $\mathrm{z}$ tajemnicą przybliżoną za pomocą poetycko-teologicznej formuły „Prasakrament” (Poezje, dramaty, szkice 515), odnoszącej się do doświadczenia poetycko dookreślonego jako ,[...] samo bycie widzialnym znakiem odwiecznej Miłości” (Poezje, dramaty, szkice 516). Zarazem teologiczne poszukiwania „prasakramentu” pozostają w pośrednim związku z obecnym w kulturze europejskiej namysłem nad pięknem, którego więź z dobrem i prawdą została osłabiona. Ów związek nie wynika tylko z kontekstu sztuki europejskiej przywołanego w poemacie i Liście do artystów, ale również ze sposobu rozumienia tajemnicy „prasakramentu”. Chociaż bowiem określenie to odnosi się do sytuacji, w której następuje „[...] wzajemne obdarowywanie pełnią prawdy, dobra i piękna" (Poezje, dramaty, szkice 515), to jednak zarazem chodzi o ludzką kondycję sprzed grzechu, kiedy pierwsi ludzie nie odczuwali wstydu, lecz żyli w stanie uniesienia (Poezje, dramaty, szkice 516). Ich pierwszym doświadczeniem, najważniejszym narzędziem poznania było więc czyste spojrzenie prowadzące do zachwytu nad pięknem - zgodnie z określeniem, że „prasakrament” to bycie widzialnym znakiem miłości. Stan permanentnego uniesienia pozwalał im doświadczać - na wzór Stwórcy - pełni prawdy, dobra i piękna, ale zarazem to właśnie doznanie piękna było dla nich pierwotne.

Zadeklarowana przez Wojtyłę przy okazji lektury pism Jana od Krzyża postawa intelektualna i artystyczna polegająca na zwróceniu się ku sztuce w poszukiwaniu narzędzi pozwalających wyrazić doświadczenie rzeczywistości, w tym również doświadczenie wiary, daje w tej poezji efekt w postaci dążenia do obiektywizacji przekazu. Narzędziami poetyckimi służącymi temu celowi są: „refleksja, spokojne wyznanie, sprawozdanie, równoważnik obrazowy” (Dybciak, „Poetycka fenomenologia" 153). Literaturoznawca traktuje ten ostatni element jako znak wspólnoty artystycznej z poetami posługującymi się podobnymi środkami poetyckiego wyrazu. W cytowanym już studium padają dwa przykłady: Thomas Stearns Eliot i jego „korelat obiektywny" oraz krakowska awangarda i jej teoria ekwiwalentyzacji uczuć (Dybciak, „Poetycka fenomenologia” 153). Jesteśmy tutaj zatem - powtórnie - w kręgu mocnego oddziaływania modernizmu. Jest więc ono czytelne nie tylko na poziomie kulturowego kontekstu rozpoznania przez Wojtyłę i Jana Pawła II uprzywilejowanej roli sztuki w procesie poznawania rzeczywistości, ale również na płaszczyźnie jego języka poetyckiego. 
Pozostawanie Wojtyły w kręgu tej tradycji to skutek zarówno pośredniego wpływu dziedzictwa literatury polskiej dwudziestolecia międzywojennego ${ }^{6}$, jak i bezpośrednich relacji interpersonalnych. W tej drugiej kategorii być może najważniejsza była znajomość z Mieczysławem Kotlarczykiem ${ }^{7}$ założycielem Teatru Rapsodycznego. Karol Wojtyła należał do tego zespołu i pozostawał w kręgu oddziaływania tych samych myśli i dzieł, których uchwytnym analitycznie wyrazem jest wydana po wojnie książka Kotlarczyka, do której jeszcze wrócimy.

Interesującym przykładem zanurzenia młodego Wojtyły w kulturze polskiej modernizacji lat międzywojennych jest odnaleziony niedawno jego utwór, pochodzący prawdopodobnie z lat 1941-1942 [Ciagle jestem na tym samym brzegu]. To medytacyjna proza składająca się z dziesięciu segmentów, przypominająca nieco sposobem konstruowania opowieści jego późniejszy dramat Przed sklepem jubilera-monolog wewnętrzny, czasami bardzo skondensowany myślowo i przybierający kształt poetycki współbrzmi z krótkimi scenami dramatycznymi zawierającymi dialogi. W drugim segmencie utworu pojawia się opis pewnej sytuacji z życia codziennego. Wyłączenie elektryczności w mieście spowodowało, że pokój oświetlała tylko świeca stojąca na stole. Wpatrywanie się w grę świateł zrodziło pewną ogólniejszą refleksję:

Pokój tonął wskutek tego w charakterystycznej pomroce, która w domu sprawia zawsze niemiłe wrażenie. Jak gdyby mieszkanie kochało się w pewnych zdecydowanych odcieniach, np. sympatyczna bywa taka szara godzina, gdy światło sączy się przez firanki z latarni ulicznej i wydobywa zaledwie poszczególne płaszczyzny ze sprzętów, a pali się w szkłach, sprawiając wrażenie jakoby trzeci wymiar nie istniał, a otoczenie utworzone tylko z płaszczyzn i z blasków znieruchomiało wprost w jakimś czwartym wymiarze. Sprawia to nastrój jakiegoś właśnie zawieszenia: chwila przed decyzją, która jednakże nigdy nie nastąpi. Ale wnętrze pokoju oświetlone świecą nie daje tej satysfakcji, przeciwnie powstaje z tego coś kłaczastego, pobrudzonego i brzeg, który się osuwa, ale nigdy całkiem nie utonie. (Wojtyła, Dzieła literackie i teatralne 1: 308-309)

Mamy tutaj do czynienia z językiem artystycznym podobnym do form wypowiedzi charakterystycznych dla literatury „epifanijnego wyrazu” (Nycz 45). Zwyczajna, codzienna sytuacja staje się punktem wyjścia do uważnej obserwacji najbliższego otoczenia przekształcającej się w autorefleksję. W centrum tego artystycznego komunikatu znajduje się chwila. W niej kumuluje się wzrokowe wrażenie będące skutkiem patrzenia na grę świateł, a zarazem stan ducha i umysłu polegający na poczuciu zawieszenia, przygotowania do podjęcia decyzji, która jednak nie zostanie podjęta. Oszczędnie skomponowane tło fabularne czy też dramatyczne (bo nie jest

\footnotetext{
${ }^{6}$ Najczęściej wskazuje się, że w twórczości młodego Wojtyły widoczna jest lektura Ballad o powsinogach beskidzkich Emila Zegadłowicza (zob. Maciejewski 127).

${ }^{7}$ George Weigel formułuje nawet sąd ogólniejszy, odnoszący się do wpływu Kotlarczyka na Karola Wojtyłę, wykraczającego poza kontekst przynależności do Teatru Rapsodycznego, bo dotyczącego całościowego myślenia „o relacji głoszonego słowa do dynamiki historii” (Weigel 55).
} 
oczywiste, do którego rodzaju literackiego przypisać ten utwór) zawiera między innymi informację, że w kręgu zainteresowania narratora i bohaterów znajduje się pisarstwo Jorisa-Karla Huysmansa, na pewno jego powieść Katedra. Bohaterowie zastanawiają się nad wywiedzioną z tej twórczości ideą ,,ównoważnego przeciwstawienia" (Wojtyła, Dzieła literackie i teatralne 1: 309), co jest chyba nawiązaniem do głośnej książki $N a$ wspak. Przedmowę do kolejnego jej wydania, datowaną na rok 1903, autor zakończył cytatem z artykułu Barbeya d'Aurevilly’ego, którego głos na temat $N a$ wspak Huysmans uznał za najtrafniejszy: „Po takiej książce autorowi pozostaje już tylko wybrać pomiędzy lufą pistoletu a stopami krzyża” (Huysmans 45).

Za sprawą dzieła Huysmansa jesteśmy w utworze Karola Wojtyły w centrum europejskiego modernizmu $\mathrm{z}$ jego dylematami i transgresjami. Ich echo jest $u$ polskiego poety ściszone, pozbawione naturalistycznej, nierzadko wulgarnej dosłowności. Zarazem jednak całe to dziedzictwo - budzące w autorze Katedry i zachwyt, i odrazę - położone na szalach mających zważyć racje i pozwolić podjąć życiową decyzję pozostaje kontekstem wyboru, o którym mówi narrator medytacji Wojtyły. On bowiem, tak jak bohater Huysmansa, również stoi przed jakimś zasadniczym wyborem, podobnie zresztą jak i sam Wojtyła coraz bliższy wówczas podjęcia życiowej decyzji o kapłaństwie. Wspomniany już obraz wieczornej medytacji, prowadzący do artystycznego zatrzymania „,chwili przed decyzją, która ... nie nastąpi”, pozostaje w bezpośrednim związku z tymi życiowymi dylematami.

$\mathrm{W}$ medytacji [Ciagle jestem na tym samym brzegu] następuje przekroczenie owej chwili permanentnego zawieszenia. Obrazowym ekwiwalentem tego przekroczenia jest światło świecy adwentowej: ,tylko w tym jedynym wypadku świece doskonale rozłamują nasze psychiczne oczekiwanie i stwarzają właściwą koncentrację" (Dzieła literackie i teatralne 1: 309). Ów obraz nie mieści się jednak w ramach opisanego doświadczenia - został przywołany jako perspektywa możliwa, ale odmienna od zaktualizowanej w tej wieczornej mikromedytacji. W granicach doświadczenia w niej relacjonowanego to nie światło świecy, ale poblask elektrycznego światła wyraża nastrój właściwy chwili przed decyzją. Artystyczne oswojenie światła elektrycznego - ważnego symbolu nowoczesności - też jest zresztą tutaj drobnym, ale znaczącym szczegółem potwierdzającym na płaszczyźnie obrazowania poetyckiego wpływ epoki nowoczesnej na twórczość Wojtyły.

\section{KONTEKST „ETYKI AUTENTYCZNOŚCI”}

Sztuka żywego słowa Mieczysława Kotlarczyka - to dzieło będące świadectwem głębokiego zanurzenia autora i jego środowiska w kulturę polskiego modernizmu. Powstawało ono od lat powojennych (1953), a ukończone zostało w roku 1975. 
W roku 1974 Karol Wojtyła - jako metropolita krakowski - napisał przedmowę do tego opus magnum swojego nauczyciela i przyjaciela. Książka Kotlarczyka oprócz uwag warsztatowych porusza też kwestie bardziej ogólne, dając pewien wgląd w sposób myślenia autora o roli artysty w czasach współczesnych. Biorąc pod uwagę czas powstawania dzieła oraz trwałość więzi Wojtyły z jego autorem (unaocznioną w przedmowie), można zakładać, że główne idee książki były przedmiotem intelektualnego dialogu obydwu autorów.

Interesujące, że Kotlarczyk poświęca dużo uwagi kwestii nowoczesności sztuki żywego słowa - czyni ją tematem jednego z rozdziałów. Nowoczesność jest tutaj rozumiana jako kontekst stawiający sztuce wymagania pozwalające oczyścić ją z fałszu i braku autentyzmu: „W zgodzie z nowoczesnością pozostaje każdy postulat, żeby język interpretacyjny utrzymać na gruncie prawdy i prostoty wszystkich środków wyrazu" (Kotlarczyk 280). Ta uwaga odnosi się - jak wynika z dalszej części rozważań - również do „artystycznych środków wyrazu w ogóle” (Kotlarczyk 281). Kotlarczyk rozumie tę skonstatowaną w nowoczesności potrzebę jako uniwersalny imperatyw sztuki, a na potwierdzenie swojej intuicji przywołuje przykład Norwida: „Prostotę i prawdę można odnaleźć np. w Norwidowskiej teorii białego kwiatu, czyli teorii ściszenia, stonowania, odpatetyzowania i dyskrecji środków artystycznego wyrazu" (Kotlarczyk 281). Chodzi tutaj zatem o takie pojmowanie wyzwań nowoczesności, że okazują się one możliwe do odnalezienia u Norwida, a więc poety wyjątkowo ważnego dla Jana Pawła II.

Motywacją dążenia do prawdy i prostoty języka sztuki jest - według Kotlarczyka - poszukiwanie autentyzmu:

[...] społeczeństwo dzisiejszych czasów postuluje: jak najmniej fałszu, patosu, przesady i sztuczności - a jak najwięcej prawdy i prostoty. [...] Od niczego bardziej nie chcemy się jako słuchacze odżegnać dzisiaj, jak od wszelkiej blagi i kłamstwa, zgrywania się i udawania, emfazy i pozy, afektacji, egzaltacji i ekshibicjonizmu. [...] Wierzymy tylko artyście przejętemu, który najpierw musi sam przejąć się i zachwycić słuchacza. (Kotlarczyk 282)

Przekonanie, że autentyzm sztuki dążącej do prawdy i prostoty jest podstawową potrzebą estetyczną odbiorców, współbrzmi z rozumieniem poezji Norwida przez Jana Pawła II. W liście z okazji 180. rocznicy urodzin poety Papież wskazał między innymi właśnie na rozpoznanie prawdy człowieczeństwa jako na zasadniczy punkt odniesienia artystycznej postawy Norwida: ,[...] człowiek dostrzega, że prawda ludzkich dążeń przerasta go nieskończenie. Z niej jest jego wolność" (Poezje, dramaty, szkice 581). Wybrzmiewa tutaj wspólnota myśli z Kotlarczykiem zarówno w zakresie wyboru autorów, jak i rozumienia ich twórczości.

Konteksty kultury przywoływane przez Kotlarczyka jako wzmacniające siłę jego argumentacji pochodzą między innymi z twórczości takich autorów, jak Stanisław 
Wyspiański (Kotlarczyk 398), Stanisław Przybyszewski (Kotlarczyk 395), Julian Przyboś (Kotlarczyk 279) czy Tadeusz Peiper (Kotlarczyk 274). Są to wypowiedzi pisarzy współtworzących w literaturze polskiej dziedzictwo modernizmu. Tak też postrzega je Kotlarczyk, poszukując w nich intuicji odnoszących się do artystycznych wyzwań nowoczesności. Korzystając z tego dziedzictwa, formułuje on wniosek: "Obowiązuje zasada maksymalnego wyrazu przy użyciu minimalnych środków" (Kotlarczyk 277). O tych nie tylko ściśle warsztatowych, ale również intelektualnych i duchowych poszukiwaniach Kotlarczyka Karol Wojtyła pisał w przedmowie do Sztuki żywego słowa, że wyrażały polskie i chrześcijańskie tradycje sztuki, „które przekazała nam cała nasza literatura, a przede wszystkim wielka literatura romantyczna i neoromantyczna" (Kotlarczyk 11). Słowa te są potwierdzeniem listu Wojtyły do Kotlarczyka z 28 grudnia 1939 roku, w którym znalazło się między innymi wyznanie: „Przeczytałem całą prawie mistykę Słowackiego, potem wiele z Mickiewicza, teraz na nowo Wyspiańskiego ab ovo" (Wojtyła, Dzieła literackie i teatralne 359). Świadczą one o trwałości zainteresowania Karola Wojtyły twórczością nie tylko romantyków, ale i neoromantyków, a szczególnie Wyspiańskiego ${ }^{8}$.

Uwrażliwienie na autentyczność sztuki, na jej gotowość poszukiwania prawdy o człowieku i wyrażania jej w sposób tak wiarygodny, jak to jest możliwe tylko dzięki artystycznym środkom wyrazu, współgra z modernistycznym dziedzictwem tak zwanej etyki autentyczności. Jej podstawowym przeświadczeniem jest przekonanie, że poczucie „doniosłości ludzkiego życia i jego codziennych celów... ma źródło w ludzkim wnętrzu. Jest to wewnętrzny impuls lub przeświadczenie, które mówi nam o znaczeniu naszych własnych naturalnych celów i naszej solidarności z bliźnimi w ich próbach osiągnięcia tych celów. Jest to głos natury w nas samych" (Taylor, Źródta podmiotowości 681) ${ }^{9}$. W A Secular Age Taylor wyjaśnia, że owa „etyka autentyczności” wywodzi się co prawda z epoki romantyzmu, ale oddziałała na kulturę następnych wieków, aż do współczesności $(299)^{10}$. Charakterystyczne, że Światowe Dni Młodzieży - praktykę duszpasterską wprowadzoną w życie przez Jana Pawła II - Taylor określa jako „formę chrześcijańskiej pielgrzymki/zgromadzenia wiernych przeznaczoną na epokę autentyczności” (A Secular Age 517).

Co bardzo ważne, Jan Paweł II nie poprzestaje na naturalistycznym rozumieniu źródeł owego poczucia „doniosłości ludzkiego życia”, ale zakorzeniając je w intuicjach i prawdach teologicznych, troszczy się o mocne osadzenie uznanych prawd

\footnotetext{
${ }^{8}$ Wyspiańskiego przypomniał Jan Paweł II podczas dwóch pielgrzymek do Polski. („Raduj się, Krakowie, oddając hołd świętej Pani Wawelskiej” 57 oraz „W duchu wdzięczności i odpowiedzialności za owocowanie wiary" 100).

${ }^{9}$ Książką Taylora w całości poświęconą tej problematyce jest Etyka autentyczności.

${ }^{10}$ Dzieło Taylora zostało opublikowane w roku 2007.
} 
w doświadczeniu wewnętrznym. Doniosłość ludzkiego życia nie ma dla niego źródła w ludzkim wnętrzu, lecz jako prawda egzystencjalna staje się przekonująca, gdy zostanie zinterioryzowana. Na pewno zaś owo uwewnętrznienie jest sprawdzianem autentyczności wyrazów doniosłości ludzkiego życia w języku sztuki. Taki też jest sens uwagi Jana Pawła II w Liście do artystów: „Każda autentyczna inspiracja artystyczna wykracza ... poza to, co postrzegają zmysły, i przenikając rzeczywistość, stara się wyjaśnić jej ukrytą tajemnicę. Ma swoje źródło w głębi ludzkiej duszy - tam, gdzie pragnienie nadania sensu własnemu życiu łączy się z nieuchwytnym doznaniem piękna i tajemniczej jedności rzeczy" (Poezje, dramaty, szkice 565). Ujawnia się tutaj konsekwencja w stosunku do zasadniczych przeświadczeń sformułowanych w książce Osoba i czyn, która była wyrazem wypracowywania przez Karola Wojtyłę własnego stanowiska filozoficznego, biorącego pod uwagę, że: „Człowiek nie może zagubić właściwego sobie miejsca wśród tego świata, który sam ukształtował”. Jeden z fundamentów rozważań w tym dziele to przeświadczenie, że: „Osoba jest [...] tym, kto siebie samego posiada - i zarazem tym, kto jest posiadany tylko i wyłącznie przez siebie” (110). Ludzka osoba, jej „samostanowienie” - przedmiot trzeciego rozdziału rozprawy, a zarazem wielki temat formacji modernistycznej w różnych jej odmianach, zawsze uwrażliwionej na ludzką podmiotowość - jest więc ważnym punktem odniesienia w rozważaniach o ludzkiej aktywności, również aktywności artystycznej.

Wolność, autonomia, tożsamość - tematy myśli i sztuki modernistycznej ${ }^{11}$ - są ważne również dla Karola Wojtyły i Jana Pawła II. Jego twórczość jest dobrze osadzona w realiach filozoficznych i artystycznych swojego czasu. Starałem się mocniej i konsekwentniej niż dotychczas unaocznić ten związek. Następnym krokiem - w innym możliwym studium - mogłoby być wnikliwsze zastanowienie się, na czym polega specyfika ujęcia tych tematów w twórczości Karola Wojtyły ${ }^{12}$.

\footnotetext{
${ }^{11}$ Zob. Grad 152.

${ }^{12}$ Jedną z możliwych ram myślowych takiej analizy mogłoby być odróżnienie dojrzałego modernizmu od nowoczesności (High Modernism vs modernity) - zob. Wolfe 23-28.
} 


\section{BIBLIOGRAFIA}

Bolecki, Włodzimierz. Modalności modernizmu. Studia. Analizy. Interpretacje. IBL PAN. Wydawnictwo: Fundacja Akademia Humanistyczna, 2012.

Dybciak, Krzysztof. „The Poetic Phenomenology of a Religious Man. About the Literary Creativity of Karol Wojtyła". Przeł. Alice-Catherine Carls. World Literature Today, nr 2, 1980, ss. 223-229.

Rozszerzona wersja artykułu „The Poetic Phenomenology”: Krzysztof Dybciak. „Poetycka fenomenologia człowieka religijnego. O literackiej twórczości Karola Wojtyły”. Sacrum w literaturze, red. Jan Gotfryd, Maria Jasińska-Wojtkowska, Stefan Sawicki, TN KUL, 1983, ss. 149-166.

Dybciak, Krzysztof. Trudne spotkanie. Literatura polska XX wieku wobec religii. Wydawnictwo Arcana, 2005.

Grad, Paweł. „Wojtyła i nowoczesna mitologia podmiotu”. Christianitas, nr 60-61, 2015, ss. 152-164.

Huysmans, Joris-Karl. Na wspak. Przeł. i wstępem poprzedził Julian Rogoziński, Czytelnik, 1976.

Jan Paweł II. „Raduj się, Krakowie, oddając hołd świętej Pani Wawelskiej”. L'Osservatore Romano, wyd. pol., nr 7, 1997.

Jan Paweł II. „W duchu wdzięczności i odpowiedzialności za owocowanie wiary”. L'Osservatore Romano, wyd. pol., nr 8, 1999.

Jędraszewski, Marek. „«Przemijanie ma sens». Antropologia Tryptyku rzymskiego Jana Pawła II”. Pisarstwo Karola Wojtyły - Jana Pawła II w oczach krytyków i uczonych. Antologia, oprac. Krzysztof Dybciak, PIW, 2019, ss. 236-260.

Kotlarczyk, Mieczysław. Sztuka żywego słowa. Dykcja. Ekspresja. Magia. Wydawnictwo Archidiecezji Lubelskiej „Gaudium”, 2010.

Kozłowska, Anna. „Wobec tradycji literackiej. Poezja z ducha Norwida”. Pisarstwo Karola Wojtyły - Jana Pawła II w oczach krytyków i uczonych. Antologia, oprac. Krzysztof Dybciak, PIW, 2019, ss. 389-417.

Jan Paweł II. „List do artystów”. Karol Wojtyła. Poezje, dramaty, szkice. Jan Paweł II. Tryptyk rzymski. Wstęp Marek Skwarnicki, Znak, 2004.

Maciejewski, Jarosław. „Karol Wojtyła i Jan Paweł II wobec literatury”. Pisarstwo Karola Wojtyły Jana Pawła II w oczach krytyków i uczonych. Antologia, oprac. Krzysztof Dybciak, PIW, 2019, ss. $121-156$.

Miłosz, Czesław. Wiersze wszystkie. Znak, 2011.

Nycz, Ryszard. Literatura jako trop rzeczywistości. Poetyka epifanii w nowoczesnej literaturze polskiej. Towarzystwo Autorów i Wydawców Prac Naukowych Universitas, 2001.

Pisarstwo Karola Wojtyly - Jana Pawła II w oczach krytyków i uczonych. Antologia, oprac. Krzysztof Dybciak, PIW, 2019.

Scruton, Roger. The Aesthetics of Music. Oxford University Press, 1997.

Skrendo, Andrzej. Poezja modernizmu. Interpretacje. Universitas, 2005.

Szymański, Wiesław Paweł. Z mroku korzeni. O poezji Karola Wojtyty. Wydawnictwo Calvarianum, 1989.

Taylor, Charles. Sources of the self: the making of the modern identity. Cambridge University Press, 2001.

Taylor, Charles. Etyka autentyczności. Przeł. Andrzej Pawelec, Znak, 2002.

Taylor Charles. A Secular Age. The Belknap Press of Harvard University Press, 2007.

Taylor, Charles. Źródła podmiotowości. Narodziny tożsamości nowoczesnej. Przeł. Marcin Gruszczyński i in., naukowo oprac. Tadeusz Gadacz, wstępem poprzedziła Agata Bielik-Robson, PWN, 2012.

Taylor, Charles. The Language Animal. The Full Shape of the Human Linguistic Capacity. The Belknap Press of Harvard University Press, 2016.

Weigel, George. Świadek nadziei. Biografia papieża Jana Pawła II. Tłum. Dominika Chylińska i in., Znak, 2000. 
Wojtyła, Karol. „O humanizmie św. Jana od Krzyża”. Znak, nr 1, 1951, ss. 6-20.

Wojtyła, Karol. Osoba i czyn. Polskie Towarzystwo Teologiczne, 1969.

Wojtyła, Karol. Poezje, dramaty, szkice. Jan Paweł II. Tryptyk rzymski. Wstęp Marek Skwarnicki, Znak, 2004.

Wojtyła, Karol. Dzieła literackie i teatralne, t. 1: Juwenilia (1938-1946), red. Jacek Popiel i in., Znak, 2019.

Wolfe, Gregory. Beauty Will Save the World. Recovering the Human in an Ideological Age. Intercollegiate Studies Institute, 2011.

Wokót „, Tryptyku rzymskiego” Jana Pawła II, red. Alfred M. Wierzbicki, TN KUL, 2003.

\section{KAROL WOJTYŁA A NOWOCZESNOŚĆ}

Streszczenie

Artykuł unaocznia związki twórczości Karola Wojtyły i Jana Pawła II z dziedzictwem myśli i sztuki modernistycznej. Jako wyznaczniki tego związku przyjęto: uprzywilejowanie języka sztuki, możliwość jej kontrmoralności oraz etykę autentyczności. Owe związki zostały ukazane tak, by podjąć polemikę z dobrze ugruntowanym w literaturze przedmiotu przekonaniem, że twórczość Wojtyły pozostała niezależna od wpływów nowoczesnej estetyki. W artykule wzięto pod uwagę nie tylko twórczość literacką, ale również pisma filozoficzne i teologiczne Karola Wojtyły/Jana Pawła II, szczególnie Osobę $i$ czyn oraz List do artystów. Ważnym kontekstem rozważań są: wywiedziona z myśli Kanta kontrmoralność sztuki oraz Charlesa Taylora etyka autentyczności.

Słowa kluczowe: Jan Paweł II; modernizm; zbawcze piękno; etyka autentyczności

\section{KAROL WOJTYŁA AND MODERNITY}

\section{Su m mary}

This article shows the relationship between the works of Karol Wojtyła / John Paul II and the heritage of modernist thought and art. The signs of such a relationship are the privileging of the language of art, the possibility of the counter-morality of art, and the ethics of authenticity. These relationships have been selected so as to refute the statement that the works of Karol Wojtyła were independent of the influences of modern aesthetics. Not only have the literary works of Karol Wojtyła / John Paul II been taken into consideration in this article, but also his philosophical and theological works, especially Person and Act and Letter to Artists. The conception of the counter-morality of art, as derived from Kant's works, and Charles Taylor's concept of the ethics of authenticity are the framework for this deliberation.

Keywords: John Paul II; modernism; salvific beauty; ethics of authenticity 